\title{
Preferential suppression of yellow head virus (YHV) envelope protein gp116 in shrimp that survive challenge with YHV
}

\author{
Parin Chaivisuthangkura ${ }^{1}$, Thanawan Tejangkura ${ }^{1}$, Sombat Rukpratanporn ${ }^{2}$, \\ Siwaporn Longyant ${ }^{1}$, Weerawan Sithigorngul ${ }^{1}$, Paisarn Sithigorngul ${ }^{1, *}$ \\ ${ }^{1}$ Department of Biology, Faculty of Science, Srinakharinwirot University, Bangkok 10110, Thailand \\ ${ }^{2}$ Center of Excellence for Marine Biotechnology at Chulalongkorn University, National Center for Genetic Engineering and \\ Biotechnology (BIOTEC), Bangkok 10330, Thailand
}

\begin{abstract}
The DNA sequence that encodes the first 406 amino acid residues at the N-terminus of yellow head virus (YHV) protein gp116, namely N/2 gp116 $\mathrm{TM}$, and the DNA sequence that encodes the next 392 amino acid residues at the C-terminus of gp116 (without the transmembrane region), namely C/2 gp116 $\mathrm{TTM}$, were cloned into pGEX-6P-1 plasmid and expressed in E. coli. Both recombinant proteins were expressed, purified by SDS-PAGE and used to immunize mice. The mouse antirecombinant N/2 gp116 and C/2 gp116 antisera bound specifically to both the recombinant proteins and to natural gp116 protein in YHV-infected haemolymph as shown by Western blotting and in tissues as shown by immunohistochemistry. Immunohistochemical localization of YHV using antigp116 antiserum or monoclonal antibodies specific to gp116 (V3-2B), gp64 (Y18) and p20 (Y19) revealed similar immunoreactivity patterns for all these reagents in muscle and mandibular tissue in shrimp showing gross signs of yellow head disease. However, in gill, hepatopancreas, lymphoid organ and thoracic ganglion tissues from experimental YHV-infected shrimp (Penaeus vannamei and Palaemon serrifer) that did not show signs of disease, immunoreactivity to gp116 was reduced or absent while that for gp64 and p20 remained intense. Thus, some shrimp species were able to selectively inhibit the synthesis of gp116 in a manner that was associated with absence of gross signs of disease.
\end{abstract}

KEY WORDS: Penaeus vannamei · Palaemon serrifer · Penaeus monodon · Polyclonal antibody · Yellow head virus (YHV)

Resale or republication not permitted without written consent of the publisher

\section{INTRODUCTION}

Yellow head virus (YHV) is a highly pathogenic virus that causes mass mortality in Penaeus monodon and a variety of other penaeid shrimp (Boonyaratpalin et al. 1993). Infection in $P$. monodon has been reported in southeast Asian and Indo-Pacific countries such as Thailand (Flegel et al. 1997), India (Mohan et al. 1998) and Taiwan (Wang \& Chang 2000). Along with the closely related virus, gill associated virus (GAV) from Australia (Cowley et al. 1999, 2000), YHV is classified in the new Family Roniviridae, genus Okavirus, within the Order Nidovirales (Cowley et al. 2000, Sittidilokratna et al. 2002). The YHV virions contain 3 major structural proteins with estimated molecular masses of 116 kDa (gp116), 64 kDa (gp64) and 20 kDa (p20) (Jitrapakdee et al. 2003), formerly identified as 135, 67 and $22 \mathrm{kDa}$ proteins, respectively (Nadala et al. 1997). The glycoproteins gp116 and gp64 are proteolytic products of a polyprotein encoded by a gene in ORF 3 of the YHV genome (Jitrapakdee et al. 2003). Recently, monoclonal antibodies (MAbs) specific to gp116 (V32B), gp64 (Y18) and p20 (Y19) were produced (Sithigorngul et al. 2000, 2002), and used for detection of 
YHV infection. By means of immunohistochemistry, MAbs Y18 and Y19 were shown to react strongly with P. monodon tissues infected with YHV or GAV, while MAb V3-2B reacted with YHV only (Soowannayan et al. 2003). A similar pattern of reaction was also observed in palaemonid shrimp experimentally infected with YHV that showed different degrees of tolerance to the YHV infection (Longyant et al. 2005). Phage display analysis revealed that MAb V3-2B recognized an epitope in the first 25 amino acid residues from the $\mathrm{N}$ terminus of gp116 that was either missing from or different in GAV (Jitrapakdee et al. 2003). From our earlier studies in experimentally YHV-infected Palaemon serrifer, Palaemon styliferus, Macrobrachium lanchesteri, Metapenaeus affinis and Metapenaeus brevicornis, immunoreactivities against gp64 (using MAb Y18) and p20 (using MAb Y19) were easily observed, whereas immunoreactivity against gp116 (using MAb V3-2B) was very weak and inconsistent (Longyant et al. 2005, 2006). However, it was difficult to conclude with confidence whether lack of MAb V3-2B immunoreactivity was due to lack of gp116 in infected shrimp tissues or due to altered gp116 epitopes. To answer this question, we prepared polyclonal antibodies to different epitopes of gp116 and used these to study gp116 expression by immunohistochemistry. Specifically DNA sequences encoding the first 406 amino acid residues at the N-terminus (N/2 gp116 $\Delta$ TM) and the next 392 amino acid residues at the $\mathrm{C}$-terminus $(\mathrm{C} / 2$ gp116 $\Delta \mathrm{TM}$ ) of gp116 were cloned and expressed in $E$. coli. The polyclonal antisera raised against the expressed recombinant proteins were used to locate gp116 in YHV-infected shrimp.

\section{MATERIALS AND METHODS}

Monoclonal antibodies. MAb V3-2B specific to the gp116 envelope protein (Sithigorngul et al. 2000), MAb Y18 specific to the gp64 envelope protein and MAb Y19 specific to the p20 structural protein of YHV (Sithigorngul et al. 2002) were used for comparison with the polyclonal antibodies.

Preparation of YHV infected haemolymph and tissues from Penaeus monodon. Penaeus monodon (15 to $25 \mathrm{~g})$, purchased from farms near Bangkok, were maintained in 10 ppt diluted seawater. Macrobrachium rosenbergii (15 to $30 \mathrm{~g}$ ), purchased from Ayuthaya Shrimp Market, were maintained in freshwater. Haemolymph was collected from both species and verified to be YHV-free by RT-PCR (Wongteerasupaya et al. 1997) prior to use as negative control samples. Palaemon serrifer was collected from a natural mangrove area in Chonburi province, Thailand, and maintained in 30 ppt seawater.
Stock haemolymph from experimentally YHVinfected Penaeus monodon (provided by Prof. T. Flegel, Mahidol University) was tested for the presence of YHV by RT-PCR (Wongteerasupaya et al. 1997) and then filtered through a $0.45 \mu \mathrm{m}$ membrane and diluted to $1: 500$ with $2 \times$ sterile phosphate buffered saline (PBS; $0.15 \mathrm{M}, \mathrm{pH} 7.2$ ). The diluted haemolymph was injected into $P$. monodon at approximately $2 \mu \mathrm{g} \mathrm{g}^{-1}$ body weight. At 2 to $3 \mathrm{~d}$ after inoculation with YHV, shrimp that showed slow movement were selected for collection of haemolymph. Collected haemolymph was mixed with anticoagulant (Rodriguez et al. 1995) at the ratio of 1:1. The haemolymph from each shrimp was tested for YHV by dot blotting using MAb Y19 as described previously by Sithigorngul et al. (2002). The strongly YHV-positive haemolymph samples were pooled and stored at $-70^{\circ} \mathrm{C}$ until used.

Viral preparation. The virus in the pooled haemolymph was concentrated using a 33\% saturated solution of ammonium sulfate. The resulting precipitate was harvested by centrifugation at $3000 \times g$ for $15 \mathrm{~min}$ and the pellet was re-suspended in $2 \times$ PBS and then centrifuged at $100000 \times g$ for $2 \mathrm{~h}$.

RNA isolation and cDNA synthesis. RNA from the partially purified virus was isolated using an RNeasy kit (Qiagen) as described in the product manual. cDNA was synthesized using Superscript II reverse transcriptase (Invitrogen), oligo d(T) primer and E. coli RNase H (Sambrook \& Russell 2001).

PCR amplification of N/2 gp116 $\Delta \mathrm{TM}$ and $\mathrm{C} / 2$ gp116 $\Delta$ TM. The N/2 gp116 $\Delta$ TM DNA sequence, corresponding to nucleotide positions 685 to 1218 of YHV ORF3 (Genbank accession no. AF540644), was amplified by 2 primers (135F685: CGC GGA TCC ACG ATT CTA AGT GGA ATT CCT G; and 116RN: CCT CGA GCT CTT CCA GAA CAC TGA TAG) with added restriction sites (underlined) and $P f X$ polymerase (Invitrogen) by using cDNA as the template. The $\mathrm{C} / 2$ gp116 $\mathrm{TM}$ DNA sequence, corresponding to nucleotide positions 1219 to 2394 of YHV ORF3, was amplified by 2 primers (116FC: CGG GAT CCT ATC ATG ACG GAG ATT $C$ and 135R4Eco: GGA ATT CAA ACA GCA TAG CTA CTG CCT GG) with added restriction sites (underlined) and $P f x$ polymerase (Invitrogen).

The PCR protocol consisted of initial denaturation at $94^{\circ} \mathrm{C}$ for $2 \mathrm{~min}$ followed by 35 cycles of $94^{\circ} \mathrm{C}$ for $15 \mathrm{~s}$, $55^{\circ} \mathrm{C}$ for $30 \mathrm{~s}$ and $68^{\circ} \mathrm{C}$ for $1 \mathrm{~min} 15 \mathrm{~s}$, and a final extension at $68^{\circ} \mathrm{C}$ for $20 \mathrm{~min}$.

Expression and purification of N/2 gp116 $\Delta \mathrm{TM}$ and C/2 gp116 $\Delta$ TM. The amplified fragment of $\mathrm{N} / 2$ $116 \Delta$ TM was cloned into pGEX-6P-1 (Amersham Biosciences) at the BamHI and XhoI sites while the amplified fragment of $\mathrm{C} / 2$ gp116 $\Delta \mathrm{TM}$ was cloned into pGEX-6P-1 at the BamHI and EcoRI sites. Each recom- 
binant plasmid was transformed into E. coli strain BL21. The integrity of the open reading frame in the recombinant plasmids was verified by DNA sequencing.

E. coli with each recombinant plasmid was cultured in Luria-Bertani (LB) broth to exponential phase and expression of the recombinant proteins was induced with $1 \mathrm{mM}$ isopropyl- $\beta$-D-thiogalacto-pyranoside (IPTG) for $4 \mathrm{~h}$. After centrifugation at $4000 \times g$ for $20 \mathrm{~min}$, the bacterial pellet was resuspended in $100 \mathrm{mM} \mathrm{NaH} \mathrm{PO}_{4}, 10 \mathrm{mM}$ Tris- $\mathrm{HCl}$, and $8 \mathrm{M}$ urea (pH 8) containing $1 \mathrm{mM}$ phenylmethylsulfonyl fluoride (PMSF), and sonicated until a clear lysate was obtained. The lysate was separated by SDS-PAGE with $10 \%$ polyacrylamide gel. After staining with Coomassie brilliant blue, the recombinant protein band was dissected and destained with $50 \% / 10 \%$ (v/v) methanol/acetic acid until the gel was clear. The protein was electro-eluted and dialyzed in PBS before determining the protein content (Bradford 1976). The solution was adjusted to $1 \mathrm{mg} \mathrm{ml}^{-1}$ protein, divided into small aliquots and stored at $-70^{\circ} \mathrm{C}$.

Production of mouse anti-rN/2 + rC/2 gp116 antiserum. Four Swiss albino ICR female mice were injected intraperitoneally with the combined mixture of purified recombinant N/2 gp116 and recombinant $\mathrm{C} / 2$ gp116 (rN/2 + rC/2 gp116) proteins (0.5 mg mouse $^{-1}$ ) mixed with complete Freund's adjuvant in a 1:1 ratio. Subsequently mice were injected 3 more times with the proteins mixed with incomplete Freund's adjuvant at 2 weekly intervals. One week after the 4th injection, mouse antisera were collected and absorbed overnight with the expression lysate of E. coli BL21 containing pGEX-6P-1 plasmid. Each antiserum was tested against E. coli lysate, purified recombinant proteins and partially purified YHV by Western blotting. They were also tested against various tissues from YHV-infected Penaeus vannamei and Palaemon serrifer by immunohistochemistry (method described later) as described by Sithigorngul et al. (2002). High titer and specific antisera were pooled together for further use.

Specificity testing - Western blotting. Lysates of $E$. coli BL21 with pGEX-6P-1 plasmid, E. coli with N/2 gp116-pGEX plasmid, E. coli with C/2 gp116-pGEX plasmid and partially purified YHV were separated by $15 \%$ gel SDS-PAGE according to the method described by Laemmli (1970). Samples were electrophoresed for $3 \mathrm{~h}$ at $60 \mathrm{~V}$ and part of the gel was stained using Coomassie brilliant blue R-250. For Western blot analysis, samples resolved by SDSPAGE were electro-blotted onto nitrocellulose membranes using a Transblot apparatus (BioRad). The nitrocellulose membrane was incubated in $5 \%$ blocking solution (5\% nonfat dry milk, $0.1 \%$ Triton X-100 in PBS) for 10 min, treated with MAb V3-2B or mouse anti-recombinant N/2 (rN/2) + recombinant C/2 (rC/2) gp116 antiserum (preabsorbed with E. coli lysate containing glutathione-S-transferase [GST]). After extensive washing in $0.5 \%$ blocking solution, the membranes were incubated in horseradish peroxidase conjugated goat anti-mouse IgG heavy and light chain specific antibody (GAM-HRP; BioRad) at 1:1500 dilution for $3 \mathrm{~h}$. The membrane was then washed extensively as before and incubated in a substrate mixture containing $0.006 \%$ hydrogen peroxide, $0.03 \%$ diaminobenzidine (DAB) and $0.05 \%$ cobalt chloride in PBS. The specific immunoreactivity on the nitrocellulose membranes was also confirmed by incubation with MAbs Y18 and Y19 and then processed as described previously, but incubated in the substrate mixture without cobalt chloride to yield a brown precipitate.

Sensitivity testing. YHV preparation from Penaeus monodon was serially diluted with PBS, and each dilution was spotted onto a nitrocellulose membrane strip. Each nitrocellulose strip was processed for dot blotting using mouse anti-rN/2 + rC/2 gp116 antiserum and the 3 MAbs as described previously in Western blotting. The last dilution that yielded an observable positive result was compared for 4 antibodies.

Immunohistochemistry. Cephalothoraces from experimentally YHV-infected Penaeus vannamei and Palaemon serrifer were fixed in Davidson's fixative solution for $24 \mathrm{~h}$ before processing for paraffin sectioning. Serial sections ( $8 \mu \mathrm{m}$ thickness) of head tissues were prepared and processed for indirect immunoperoxidase staining using mouse anti-rN/2 + rC/2 gp116 antiserum, MAbs V3-2B, Y18, Y19 and GAM-HRP diluted 1:1000 with $10 \%$ calf serum in PBS. Peroxidase activity was revealed by incubation with $0.03 \%$ DAB and $0.006 \%$ hydrogen peroxide in PBS. Preparations were counterstained with haematoxylin and eosin $\mathrm{Y}$ (H\&E), dehydrated in a graded ethanol series, cleared in xylene and mounted in permount (Sithigorngul et al. 2000). Positive reactions were visualized as brown coloration against pink cytoplasm and purple nuclei.

Demonstration of gp116 reduction in YHV-infected shrimp. Experimentally YHV-infected Penaeus monodon and Palaemon serrifer from previous experiments (Longyant et al. 2005) and naturally infected Penaeus vannamei (approximately $10 \mathrm{~g}$ body weight, collected from a farm in Nakornpathom province, Thailand) were assayed for YHV immunoreactivity using MAbs specific to gp116 (V3-2B), gp64 (Y18), p20 (Y19) and mouse anti-rN/2 + rC/2 gp116 antiserum. Gills from shrimp with lack or reduction of gp116 immunoreactivity were homogenized in $2 \times$ PBS (2 filaments $0.1 \mathrm{ml}^{-1}$ ). After centrifugation at $3000 \times g$ for $10 \mathrm{~min}$, the super- 
natant was separated by SDS-PAGE and tested for the presence of YHV by Western blotting in comparison with the viral preparation as described previously. The walking legs from the same shrimp were also subjected to tests for YHV infection by RT-PCR using an IQ2000 YHV/GAV test kit (Farming IntelliGene Technology Co-operation). Using this kit, YHV-positive samples exhibit a band of $277 \mathrm{bp}$ while GAV-positive samples exhibit a band of $406 \mathrm{bp}$.

\section{RESULTS AND DISCUSSION}

\section{Cloning and expression of gp116}

Several attempts were made to express the whole molecule of gp116 without the transmembrane region (gp116 $\mathrm{TM}$ ) in various $E$. coli systems, but they were not successful. However, in this study the gp116 $\Delta \mathrm{TM}$ was expressed in 2 parts, each consisting of approximately half of the gp116 $\Delta \mathrm{TM}$ linked with glutathioneS-transferase (GST) at the N-terminus. The N/2 gp116 $\Delta$ TM and the C/2 gp116 2 TM DNA sequences could be amplified as $1234 \mathrm{bp}$ and $1191 \mathrm{bp}$ PCR products, respectively (Fig. 1). These were cloned and expressed in E. coli and recombinant proteins were visualized by Coomassie blue staining. The rN/2 gp116 and $\mathrm{rC} / 2$ gp116 proteins were expressed in the

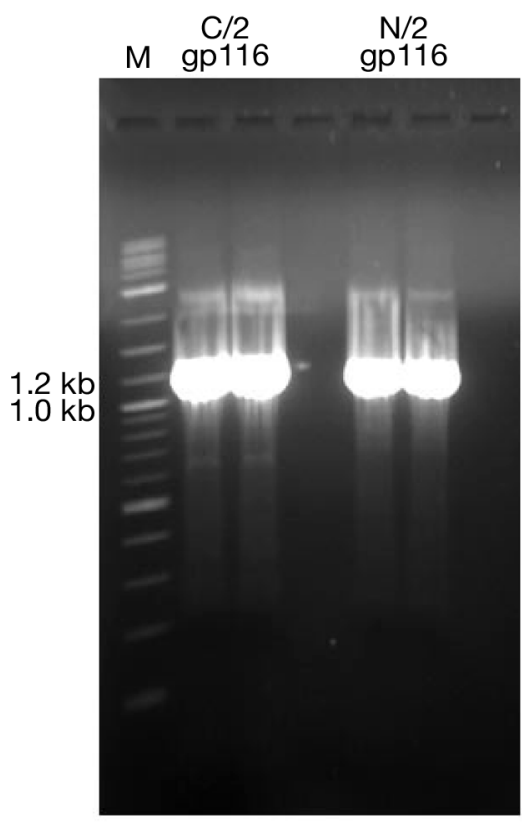

Fig. 1. PCR products of N/2 gp116 $\Delta$ TM and C/2 gp116 4 TM. $\mathrm{M}=$ DNA markers

form of GST tag fusion proteins with molecular masses of 72 and $70 \mathrm{kDa}$, respectively (Fig. 2). These recombinant fusion proteins were combined and used to generate polyclonal antibodies.

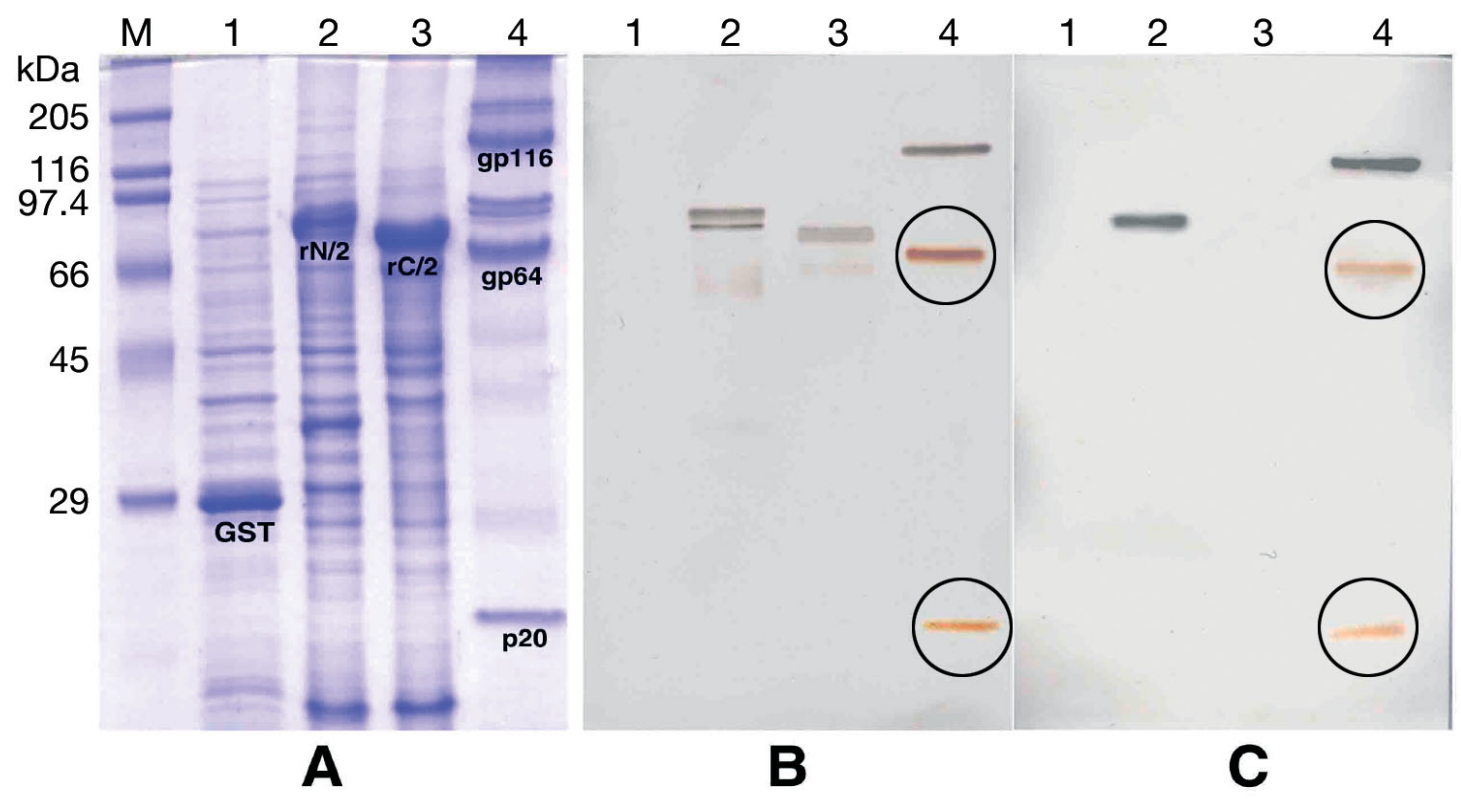

Fig. 2. SDS-PAGE and Western blot analysis for antibody specificity. (A) Lysate of E. coli BL21 with pGEX-6P-1 plasmid (lane 1), proteins of lysate of E. coli with N/2 gp116-pGEX plasmid (lane 2), lysate of E. coli with C/2 gp116-pGEX plasmid (lane 3), and partially purified YHV (lane 4) were separated in 12\% SDS-PAGE and stained with Coomassie brilliant blue. Proteins from another part of the gel were transferred to nitrocellulose membrane and (B) treated with mouse anti-rN/2 + rC/2 gp116 antiserum (preabsorbed with E. coli lysate containing GST) at 1:5000 dilution, or (C) treated with MAb V3-2B. Both membranes were re-treated with MAbs Y18 and Y19 and developed without cobalt chloride (circled bands). M = molecular weight markers 


\section{Production of mouse anti-rN/2 + rC/2 gp116 anti- serum}

After immunization of mice with rN/2 gp116 mixed with rC/2 gp116, antisera from 4 mice (mouse anti rN/2 $+\mathrm{rC} / 2$ gp116 antiserum) demonstrated specific binding to $\mathrm{rN} / 2$ gp116, rC/2 gp116 in bacterial lysates and the natural gp116 from partially purified YHV (Fig. 2B). The MAb V3-2B bound only to $\mathrm{rN} / 2 \mathrm{gp} 116$ (Fig. 2C, lane 2) and the natural gp116 (Fig. 2C, lane 4). The MAbs Y18 and Y19 bound to gp64 and p20 structural proteins of the virus, respectively (Fig. 2B,C, lane 4). This evidence confirmed that the $\mathrm{N}$ and $\mathrm{C}$ termini of gp116 protein were correctly expressed and that the expressed proteins could be used as antigens for production of specific antibodies.

\section{Sensitivity testing of mouse anti-rN/2 + rC/2 gp116 antiserum}

The detection sensitivity of YHV in viral preparations using mouse anti-rN/2 $+\mathrm{rC} / 2$ gp116 antiserum was similar to that of MAbs V3-2B, Y18 and Y19 (detection limit, 1:2000 dilution). However, MAbs V32B and Y19 showed slightly darker spots than those for MAb Y18 and mouse anti-rN/2 + rC/2 gp116 antiserum (Fig. 3). The result corresponded to Western blot results for viral preparations (see Figs. 2 \& 5) in that the intensity of all 3 viral structural proteins in viral preparations was similar.

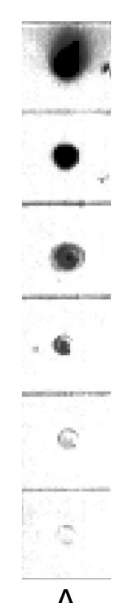

A

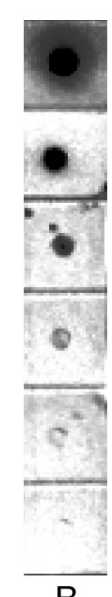

B

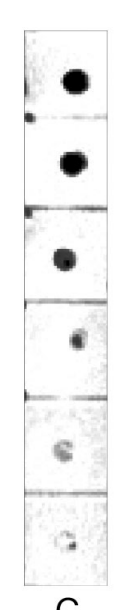

C

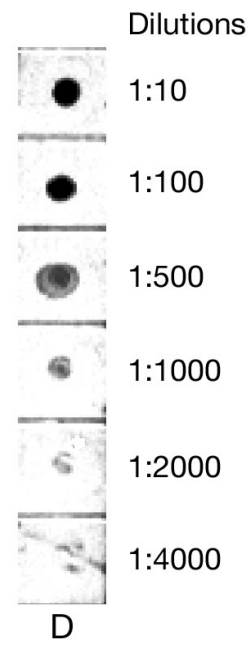

Fig. 3. Dot blots of YHV preparations. Serially diluted YHV preparations (1:10 to 1:4000 dilutions) on nitrocellulose strips were treated with the following MAbs: (A) V3-2B, (B) Y19, (C) Y18 and (D) mouse anti-rN/2 + rC/2 gp116 antiserum. The limit of detection of all 4 antibodies was similar $(\sim 1: 2000)$

\section{Reduction or absence of gp116 immunoreactivity in immunohistochemical studies}

Immunohistochemical localization of YHV infection in gill tissues of most of the challenged shrimp revealed strong immunoreactivity with MAbs Y18 and Y19 and weak or absent immunoreactivity with MAb V3-2B and mouse anti rN/2 + rC/2 gp116 antiserum (Fig. 4, column B). Only in some tissues such as those in the mandible region (Fig. 4, column A) nervous tissue, (Fig. 4, column C) and muscle did all these reagents (i.e. MAbs V3-2B, Y18, Y19 and mouse anti$\mathrm{rN} / 2+\mathrm{rC} / 2$ gp116 antiserum) exhibit strong immunoreactivity. Since the mouse anti rN/2 + rC/2 gp116 antisera contained antibodies directed to several epitopes on $\mathrm{N}$ and $\mathrm{C}$ termini of gp116, lack of immunoreactivity was probably due to a reduced quantity or lack of gp116, and not due to either absence of specific epitopes or lower affinity of MAb V3-2B and the antisera. Interestingly, nervous tissue from the same shrimp specimens gave overall immunoreactivities that were comparable for the 4 antibodies (Fig. 4, column C). However, some small neuronal processes in the gills exhibited weak or absent immunoreactivity with MAb V3-2B and mouse anti $\mathrm{rN} / 2+\mathrm{rC} / 2$ gp116 antiserum (Fig. 4, column C, rows $1 \& 3$, arrowheads) when compared with the strong overall immunoreactivity in the gills with MAbs Y18 and Y19 (Fig. 4, column C, rows 2 \& 4, arrowheads). The suppression of gp116 production varied from tissue to tissue, from shrimp to shrimp and between shrimp species. The reasons for these differences are currently unknown.

\section{Reduction or absence of gp116 immunoreactivity by Western blotting}

Western blot analysis revealed clearly that immunoreactivity to gp116 by mouse anti rN/2 $+\mathrm{rC} / 2$ gp116 antiserum (Fig. 5B) and MAb V3-2B (Fig. 5C) in gill extracts from YHV infected Penaeus vannamei was absent or reduced, while immunoreactivities of gp64 and p20 were strong (Fig. 5B,C). Partially purified YHV served as a positive control for Western blot analysis and showed strong immunoreactivity with all 4 antibodies (Fig. 5B,C, lane 2). RT-PCR tests for YHV using the IQ2000 test kit confirmed YHV infections in these shrimp was caused by the virulent Thai YHV strain used as innoculum (band at $277 \mathrm{bp}$ ) and not by GAV or other nonvirulent strains of YHV (Fig. 6). These results supported the results obtained by immunohistochemical localization tests by showing that the quantity of gp116 structural protein was indeed reduced or absent in the gill tissue. 


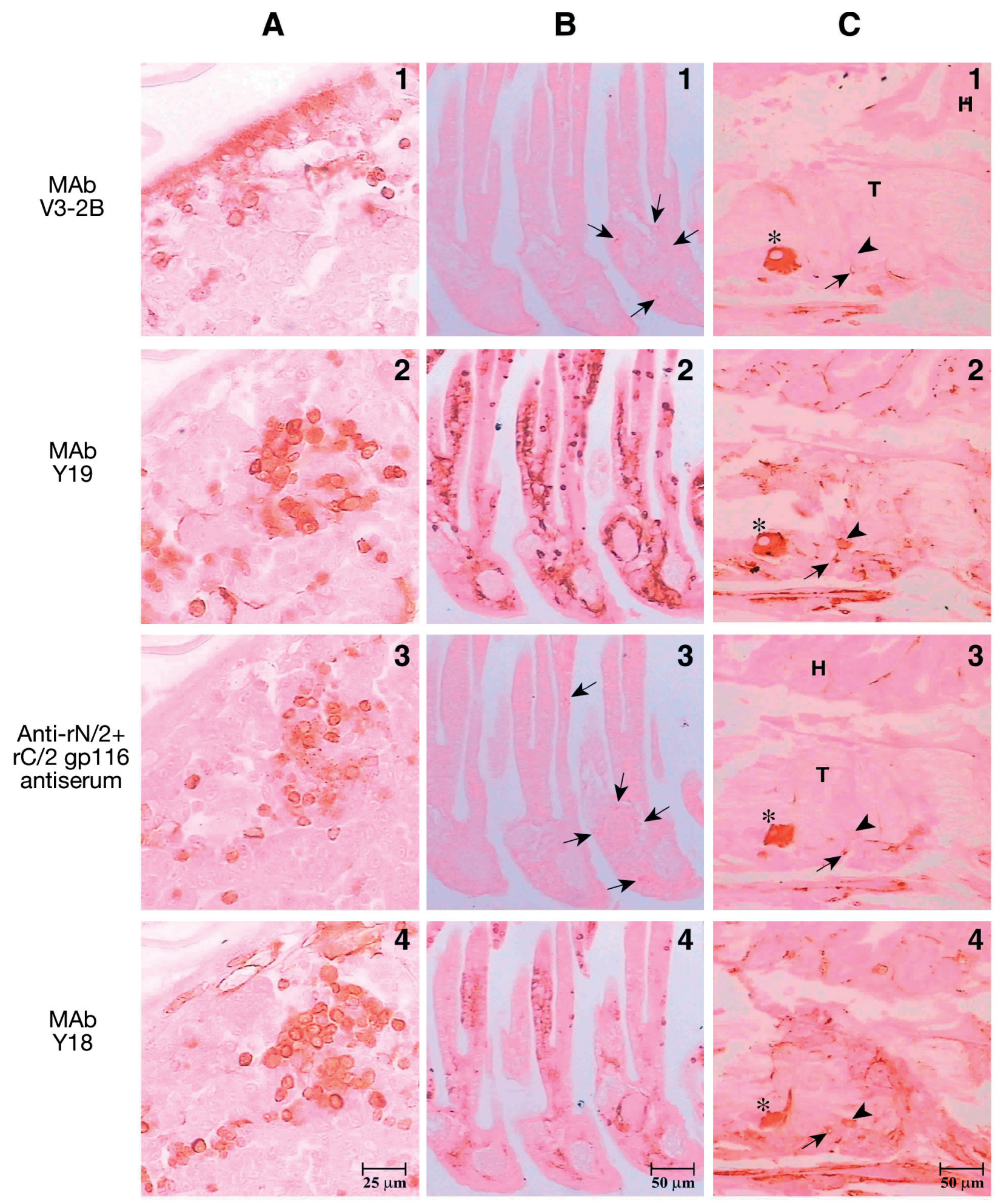

Fig. 4. Immunohistochemistry of consecutive sections of (column A) mandibular tissue from YHV-infected Penaeus vannamei, (column B) gill from the same individual of YHV-infected P. vannamei, and (column C) thoracic ganglion (T) and hepatopancreas $(\mathrm{H})$ of YHV-infected Palaemon serrifer. Each section was treated with (row 1) MAb V3-2B, (row 2) MAb Y19, (row 3) mouse anti$\mathrm{rN} / 2+\mathrm{rC} / 2$ gp116 antiserum and (row 4) MAb Y18. Arrows indicate light immunoreactivity of anti-rN/2 + rC/2 gp116 antiserum and MAb V3-2B in gill tissues and the small neuronal process. Arrowheads indicate areas where strong immunoreactivity with MAbs Y18 and Y19 in small neurons did not occur with anti-rN/2 + rC/2 gp116 antiserum and MAb V3-2B. Asterisks ( $\left.{ }^{*}\right)$ indicate the strong immunoreactivity in the same neuron 


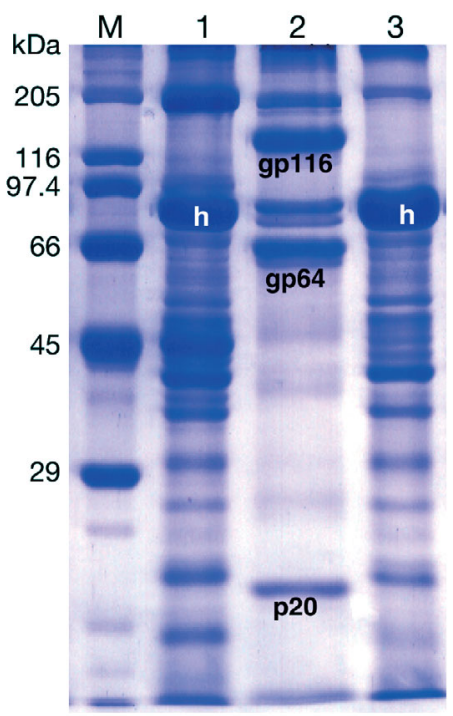

A

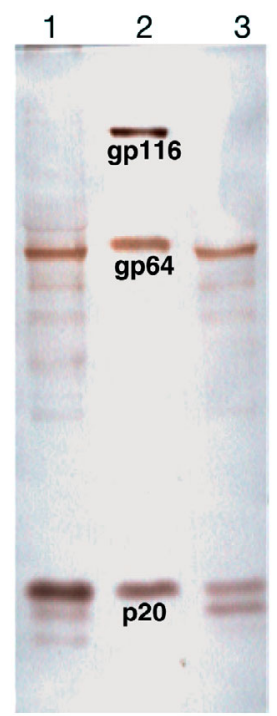

B

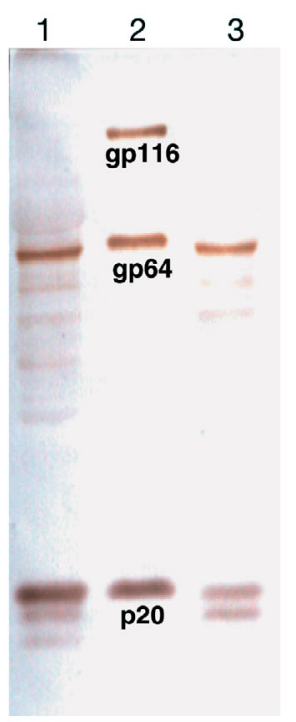

C
Fig. 5. SDS and Western blot analysis of YHV proteins. (A) Gill extracts from 2 naturally YHV-infected Penaeus vannamei (lanes $1 \& 3$ ) and partially purified YHV from P. monodon (lane 2) were separated on $12 \%$ SDS-PAGE and stained with Coomassie brilliant blue. The other part of the gel was transferred to a nitrocellulose membrane and treated with (B) mouse anti-rN/2 + rC/2 gp116 antiserum or (C) MAb V3-2B for Western blot analysis. Immunoreactivity with gp116 was absent in gill extracts from both of the $P$. vannamei samples, but was present in partially purified YHV (data not shown). $\mathrm{M}=$ molecular weight markers, $\mathrm{h}=$ haemocyanin

\section{CONCLUSIONS}

Evidence for preferential reduction in YHV envelope protein gp116 agreed with the previous reports showing that several palaemonid shrimp species and some penaeid shrimp that survived YHV challenge also showed a preferential absence of or reduction in gp116 structural protein (Longyant et al. 2005, 2006). Polyclonal antibody raised against gp116 could neutralize YHV infection in primary cultures of lymphoid organ cells, suggesting that anti-gp116 antiserum blocked the binding of YHV virions to cellular receptors that facilitate YHV entry into lymphoid organ cells (Assavalapsakul et al. 2005). Therefore, the ability to suppress gp116 in infected cells may be involved in the ability of shrimp to survive YHV challenge. Curiously gp116 is encoded upstream of gp64 in ORF3 of YHV as

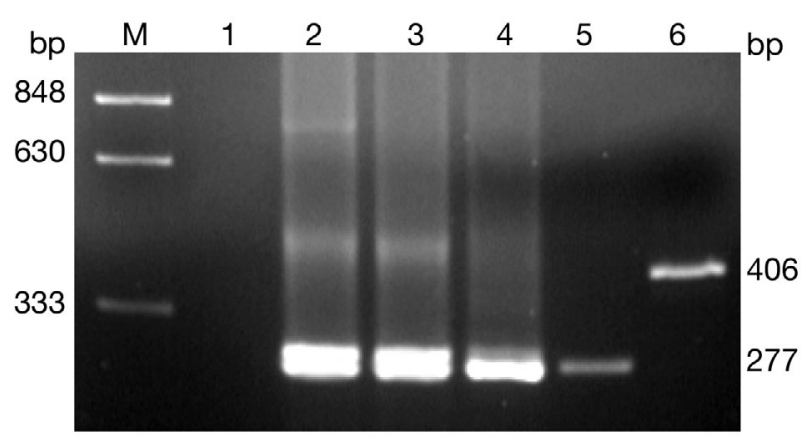

Fig. 6. RT-PCR analysis. Walking leg extracts of the same 2 naturally YHV-infected Penaeus vannamei (lanes $2 \& 4$ ) and partially purified YHV (lane 3) specimens used in Fig. 5, subjected to RT-PCR for YHV using IQ2000 test kit. Positive samples for YHV (lane 5) and GAV (lane 6) and negative control (lane 1) were included. All 3 samples tested were positive for YHV and not GAV. M = DNA markers a polyprotein transcript (Jitrapakdee et al. 2003) and the 2 proteins are released post-translation by proteolytic cleavage. Given this background, the simplest explanation for the absence of gp116 would be that it can be selectively degraded after its formation in some species or tissues, but not others. Further tests would be required to distinguish this possibility from other more complex possibilities that might be proposed to explain this very interesting phenomenon.

Since YHV is a significant pathogen in the southeast Asian and Indo-Pacific regions, the development of methods to prevent YHV infection would be beneficial. Since polyclonal antibodies raised against gp116 were successful in preventing YHV infection in cell culture (Assavalapskul et al. 2005), the recombinant gp116 plasmids and proteins developed in this study may prove useful in development of reagents for prevention of YHV infection in shrimp, as has been reported for white spot syndrome virus (Witteveldt et al. 2004a,b).

Acknowledgements. This work was supported by the Srinakharinwirot University Research Fund.

\section{LITERATURE CITED}

Assavalapsakul W, Tirasophon W, Panyim S (2005) Antiserum to the gp116 glycoprotein of yellow head virus neutralizes infectivity in primary lymphoid organ cells of Penaeus monodon. Dis Aquat Org 63:85-88

Boonyaratpalin S, Supamattaya K, Kasornchandra J, Direkbusarakom S, Ekpanithanpong U, Chantanachookin C (1993) Non-occluded baculo-like virus, the causative agent of yellow head disease in the black tiger shrimp Penaeus monodon. Fish Pathol 28:103-109

Bradford MM (1976) A rapid and sensitive method for the quantitation of microgram quantities of protein utilizing 
the principle of protein dye binding. Anal Biochem 72:248-254

Cowley JA, Dimmock CM, Wongteerasupaya C, Boonsaeng V, Panyim S, Walker PJ (1999) Yellow head virus from Thailand and gill-associated virus from Australia are closely related but distinct prawn viruses. Dis Aquat Org 36:153-157

Cowley JA, Dimmock CM, Spann KM, Walker PJ (2000) Gillassociated virus of Penaeus monodon prawns: an invertebrate virus with ORF1a and ORF1b genes related to arteriand coronaviruses. J Gen Virol 81:1473-1484

Flegel TW, Boonyaratpalin S, Withyachumnarnkul B (1997) Progress in research on yellow-head virus and white spot virus in Thailand. Disease in Asian Aquaculture III, Fish Health Sect Asian Fish Soc, Manila, p 285-295

> Jitrapakdee S, Unajak S, Sittidilokratna N, Hodgson RAJ and others (2003) Identification and analysis of gp116 and gp64 structural glycoproteins of yellow head nidovirus of Penaeus monodon shrimp. J Gen Virol 84:863-873

> Laemmli UK (1970) Cleavage of structural proteins during the assembly of the head of bacteriophage T4. Nature 227:680-685

Longyant S, Sithigorngul P, Chaivisuthangkura P, Rukpratanporn S, Sithigorngul W, Menasveta P (2005) Differences in susceptibility of palaemonid shrimp species to yellow head virus (YHV) infection. Dis Aquat Org 64:5-12

> Longyant S, Sattaman S, Chaivisuthangkura P, Rukpratanporn S, Sithigorngul W, Sithigorngul P (2006) Experimental infection of some penaeid shrimps and crabs by yellow head virus (YHV). Aquaculture 257:83-91

Mohan CV, Shankar KM, Kulkarni S, Sudha PM (1998) Histopathology of cultured shrimp showing gross signs of yellow head syndrome and white spot syndrome during 1994 Indian epizootics. Dis Aquat Org 34:9-12

Nadala ECB Jr, Tapay LM, Loh PC (1997) Yellow-head virus: a rhabdovirus-like pathogen of penaeid shrimp. Dis Aquat Org 31:141-146

Editorial responsibility: Timothy Flegel, Bangkok, Thailand
Rodriguez J, Boulo V, Mialhe E, Bachere E (1995) Characterisation of shrimp haemocytes and plasma components by monoclonal antibodies. J Cell Sci 108:1043-1050

Sambrook J, Russel DW (2001) Molecular cloning: a laboratory manual, 3rd edn. Cold Spring Harbor Laboratory Press, Cold Spring Harbor, NY

Sithigorngul P, Chauychuwong P, Sithigorngul W, Longyant S, Chaivisuthangkura P, Menasveta P (2000) Development of a monoclonal antibody specific to yellow head virus (YHV) from Penaeus monodon. Dis Aquat Org 42:27-34

Sithigorngul P, Rukpratarnporn S, Longyant S, Chaivisuthangkura P, Sithigorngul W, Menasveta P (2002) Monoclonal antibodies specific to yellow-head virus (YHV) of Penaeus monodon. Dis Aquat Org 49:71-76

Sittidilokratna N, Hodgson RAJ, Cowley JA, Jitrapakdee S, Boonsaeng V, Panyim S, Walker PJ (2002) Complete ORF1b-gene sequence indicates yellow head virus is an invertebrate nidovirus. Dis Aquat Org 50:87-93

Soowannayan C, Flegel TW, Sithigorngul P, Slater J and others (2003) Detection and differentiation of yellow head complex viruses using monoclonal antibodies. Dis Aquat Org 57:193-200

Wang YC, Chang PS (2000) Yellow head virus infection in the giant tiger prawn Penaeus monodon cultured in Taiwan. Fish Pathol 35:1-10

Witteveldt J, Vlak JM, van Hulten MCW (2004a) Protection of Penaeus monodon against white spot syndrome virus using a WSSV subunit vaccine. Fish Shellfish Immunol 16:571-579

Witteveldt J, Cifuentes CC, Vlak JM, van Hulten MCW (2004b) Protection of Penaeus monodon against white spot syndrome virus by oral vaccination. J Virol 78:2057-2061

Wongteerasupaya C, Thongcheua W, Boonsaeng V, Panyim S, Tassanakajon A, Withyachumnarnkul B, Flegel TW (1997) Detection of yellow-head virus (YHV) of Penaeus monodon by RT-PCR amplification. Dis Aquat Org 31:181-186

Submitted: June 30, 2005; Accepted: November 7, 2007

Proofs received from author(s): January 22, 2008 